\title{
Performance of Laying Hen Eggs on the Addition of Sprouts at Wakhid Farm, Magetan Regency
}

\author{
Catur Suci Purwanti ${ }^{1}$, Engkus Ainul Yakin ${ }^{2}$, and Febrian Nisa Ramadhani ${ }^{3}$. \\ 1,2,3 Program Study of Animal Husbandry, Faculty of Agriculture \\ Universitas Veteran Bangun Nusantara Sukoharjo, Indonesia \\ Corresponding Author: engkus_ainul@yahoo.com
}

\begin{abstract}
This study aimed to determine the performance of laying hen eggs on the addition of sprouts at Wakhid Farm, Magetan Regency. This research was conducted at Wakhid Farm, Magetan Regency. Sprouts were soaked for 1 day before being given to the treatment feed. This study used 4 types of treatment and each treatment consisted of 4 replications. $\mathrm{P}_{0}$ is control $\left(50 \%\right.$ corn $+15 \%$ bran +35 concentrate), $\mathrm{P}_{1}$ is $50 \%$ corn $+15 \%$ bran $+35 \%$ concentrate $+5 \%$ sprouts, $\mathrm{P}_{2}$ is $50 \%$ corn $+15 \%$ bran $+35 \%$ concentrate + $10 \%$ sprouts and $\mathrm{P}_{3}$ which is $50 \%$ corn $+15 \%$ bran $+35 \%$ concentrate $+15 \%$ sprouts. Observation parameters include feed consumption, hen day production, egg weight and egg mass. Parameters observed in the study included feed consumption, egg production, hen day production, egg weight and egg mass. The research method used RAL (Completely Randomized Design) unidirectional pattern. The data obtained were then analyzed using ANOVA (Analysis of variance). If there is a significant treatment effect, then proceed with the DMRT Test (Duncan Multiple Range Test) to determine the differences between treatments. The data obtained showed that the performance of different eggs for each treatment sample had a significant effect on feed consumption, hen day production, egg weight and egg mass. The results showed that feed consumption was between 118.7 - $118.5 \mathrm{grams} /$ day/head, hen day production was between $79.46-$ $90.17 \%$, egg weight was between $57.08-60.47$ grams and egg mass was $43.94-56.55$ grams. The conclusion was that the addition of sprouts did not affect feed consumption, hen day production and egg mass and had a significant effect on egg weight..
\end{abstract}

Keywords : eggs, laying hen, performance and sprouts.

\section{Introduction}

The prospect of laying hens in Indonesia is quite promising on both domestic and foreign markets in terms of supply and demand. The supply side of the production capacity of laying hens in Indonesia has not yet reached the actual production capacity. This can be seen from the number of breeding, animal feed and pharmaceutical companies that are still producing so that the prospect of development is still open.

Efforts are being undertaken to improve the efficiency of chicken feed utilization in order to preserve chicken productivity and health, notably by adding additives to the feed, one of which is the use of synbiotics. In order to improve the effectiveness of laying chickens feed, probiotics and prebiotics are frequently utilized as additives. 
Environmental factors such as excessive humidity and warmth can lead chickens to become stressed, resulting in lower feed consumption and lower output (Sari et al., 2017).

Sprouts are young plants that sprout from the seeds of sowed nuts / legumes (Fabaceae). Bean sprouts are sprouts that are made from mung bean seeds. Mung bean seeds have a moisture content of 5-15 percent; with this moisture content, the humidity is too low for metabolism to occur, so the first stage of germination is to increase the water content of the seeds by soaking or placing them in a water-saturated environment. This study aimed to determine the performance of laying hen eggs on the addition of sprouts at Wakhid Farm, Magetan Regency.

\section{Materials and Methods}

The research was carried out at Wakhid Farm in Takeran District, Magetan Regency for 1 week starting from June 2021. The laying hens used in this study were 64 hens aged 56 weeks. The experimental design used was a unidirectional completely randomized design (CRD). Treatments were 4 by 4 times so that $4 \times 4 \times 4=64$ experimental units were obtained, including:

$$
\begin{aligned}
& A=\text { Control Sample } \\
& B=\text { Sample Addition of } 5 \% \text { Sprouts } \\
& \text { C }=\text { Sample Addition of } 10 \% \text { Sprouts } \\
& D=\text { Sample Addition of } 15 \% \text { Sprouts }
\end{aligned}
$$

The research variables observed were feed consumption (Zainal, 2003), hen day production (Devis et al., 2016), egg weight (Kurtini, 2004) and egg mass (Didik et al., 2018).

\section{Feed Intake}

The consumption of laying hens in the era of the 2000s cannot be taken lightly. The genetic quality improvement of laying hens can be said to be very spectacular in converting the feed ingredients they consume into eggs and meat. The logical consequence is that the growth and production of chicken eggs is very dependent on the treatment it receives, including feed treatment.

\section{Hen Day Production}

Daily egg production was calculated from the number of eggs collected divided by the number of laying hens within a certain period of time in each treatment. The peak of egg production in laying hens is in the age range of 28-30 weeks with $90 \%$ egg production, so the peak production appears. Egg production is strongly influenced by the level of protein in the feed.

\section{Egg Weight}

Egg weights that do not differ or are relative is caused by the relative weight of the chickens. Chicken weight and egg weight have a positive correlation, chickens with heavier weights produce heavier eggs than chickens with light body weights. 


\section{Egg Mass}

Factors that affect egg mass are feed additive, consumption, calcium content of feed, egg size and egg weight. This increase in egg mass occurs due to an increase in Hen Day Production and egg weight, because mathematically egg mass is the product of the multiplication of Hen Day Production and egg weight so that the value will be directly proportional. One of the efforts to improve feed quality is the addition of additives in feed.

\section{Results and Discussion}

\section{Feed Intake}

Feed intake data are presented in Table 1, with analysis showing that 64 hens had no significant effect on laying hens consumption data $(\mathrm{P}>0.05)$.

Table 1. Feed Intake of Laying Hens At Wakhid Farm Magetan Regency

\begin{tabular}{lcccc}
\multicolumn{5}{c}{ (gram/head/day) } \\
\cline { 2 - 5 } Repeition & $\mathrm{P}_{0}$ & $\mathrm{P}_{1}$ & $\mathrm{P}_{2}$ & $\mathrm{P}_{3}$ \\
\cline { 2 - 5 } & 118.8 & 118.8 & 118.4 & 118.6 \\
$\mathrm{U}_{1}$ & 118.9 & 118.5 & 118.7 & 118.7 \\
$\mathrm{U}_{2}$ & 118.6 & 118.8 & 118.1 & 118.4 \\
$\mathrm{U}_{3}$ & 118.7 & 118.6 & 118.5 & 118.3 \\
$\mathrm{U}_{4}$ & 118.7 & 118.6 & 118.3 & 118.5 \\
\hline Average $^{\mathrm{ns}}$ & 118.5
\end{tabular}

Description $^{\text {ns }}:$ Non Significant

The lowest consumption data was obtained in the $\mathrm{P}_{3}$ treatment of 118.5 and the highest in the $\mathrm{P}_{0}$ treatment of 118.7. The results of this study are in accordance with the opinion of Puspitasary et al., (2018) which states that feed intake in livestock is strongly influenced by its energy content. Feed consumption will increase if fed with low energy content and vice versa will decrease if fed with high energy content feed. This is because poultry consume feed mainly to fulfill their energy. Cattle will stop eating when their energy needs are met. The timing of feeding also affects feed consumption because the longer the distance from the feeding time, the more nervous the chickens will be. The average time of administration for $\mathrm{P}_{0}, \mathrm{P}_{1}, \mathrm{P}_{2}$ and $\mathrm{P}_{3}$ treatments was at 06.00. Based on the results of the study, it can be seen that of the four treatments the lowest feed consumption data was 118.5, where the $\mathrm{P}_{3}$ treatment averaged the earliest feeding time at 06.00.

\section{Hen Day Production}

Hen day production data are presented in Table 2, with analysis showing that 64 hens had no significant effect on laying hens hen day production data $(\mathrm{P}>0.05)$. The lowest hen day production data was obtained in the $\mathrm{P}_{0}$ treatment of 79.46 and the highest in the $\mathrm{P}_{3}$ treatment of 90.17. The results of this study are in accordance with Larasati et al., (2017) egg production is influenced by ration consumption, especially protein consumption. The food factor that affects egg production is the protein content of the food, because approximately $50 \%$ of the dry weight of eggs consists of protein. The time of taking eggs also affects hen day production because the more often the distance from 
the time of retrieval, the more stressful the chickens will be to lay eggs. The time of taking eggs in treatment $\mathrm{P}_{0}, \mathrm{P}_{1}, \mathrm{P}_{2}$ and $\mathrm{P}_{3}$ on average was carried out at $14.00-15.00$. Based on the results of the study, it can be seen that from the four treatments the lowest hen day production data was 79.46, where the $\mathrm{P}_{0}$ treatment averaged egg retrieval time at 14.00 15.00 .

Table 2. Average Hen Day Production of Laying Hens At Wakhid Farm Magetan Regency (\%)

\begin{tabular}{ccccc}
\hline \multirow{2}{*}{ Repeition } & \multicolumn{4}{c}{ Handling } \\
\cline { 2 - 5 } & $\mathrm{P}_{0}$ & $\mathrm{P}_{1}$ & $\mathrm{P}_{2}$ & $\mathrm{P}_{3}$ \\
\hline $\mathrm{U}_{1}$ & 85.71 & 92.85 & 82.14 & 96.42 \\
$\mathrm{U}_{2}$ & 71.42 & 82.14 & 92.85 & 96.42 \\
$\mathrm{U}_{3}$ & 78.57 & 75.00 & 85.71 & 85.71 \\
$\mathrm{U}_{4}$ & 82.14 & 78.57 & 82.14 & 82.14 \\
\hline Average $^{\text {ns }}$ & 79.46 & 82.14 & 85.71 & 90.17 \\
\hline Description $^{\text {ns }}$ : Non Significant & & &
\end{tabular}

\section{Egg Weight}

Egg weight data are presented in Table 3, with analysis showing that 64 hens had a significant effect on egg weight data for laying hens $(\mathrm{P}<0.05)$.

Table 3. Average Egg Weight of Laying At Wakhid Farm

\begin{tabular}{lcccc}
\multicolumn{5}{c}{ Magetan Regency (gram/grain) } \\
\cline { 2 - 5 } Repeition & \multicolumn{4}{c}{ Handling } \\
\cline { 2 - 5 } & $\mathrm{P}_{0}$ & $\mathrm{P}_{1}$ & $\mathrm{P}_{2}$ & $\mathrm{P}_{3}$ \\
\hline $\mathrm{U}_{1}$ & 57.29 & 62.54 & 57.83 & 60.14 \\
$\mathrm{U}_{2}$ & 58.31 & 58.56 & 57.15 & 59.70 \\
$\mathrm{U}_{3}$ & 58.09 & 58.52 & 58.54 & 60.91 \\
$\mathrm{U}_{4}$ & 57.54 & 59.22 & 58.68 & 61.16 \\
\hline Average & $57.08^{\mathrm{a}}$ & $59.71^{\text {bc }}$ & $58.05^{\mathrm{ab}}$ & $60.47^{\mathrm{c}}$ \\
\hline
\end{tabular}

Description : Superskrip ${ }^{\mathrm{abc}}$ with different letters on the same line shows a Significant difference $(\mathrm{P}<0,05)$

The lowest egg weight data was obtained in the $\mathrm{P}_{0}$ treatment of 57.08 and the highest in the $\mathrm{P}_{3}$ treatment of 60.47. The results of this study are in accordance with Kurtini (2014) which states that the relatively same egg weights is due to the relatively the same weight of the chickens. Chicken weight and egg weight have a positive correlation, chickens with heavier weights produce heavier eggs than chickens with light body weights. The time of taking eggs in treatment $\mathrm{P}_{0}, \mathrm{P}_{1}, \mathrm{P}_{2}$ and $\mathrm{P}_{3}$ on average was carried out at $14.00-15.00$. Based on the results of the study, it can be seen that from the four treatments the lowest egg weight data was 57.08, where the P0 treatment averaged egg retrieval time at $14.00-15.00$.

\section{Egg Mass}

Egg mass data are presented in Table 4, with analysis showing that 64 hens had no significant effect on egg mass data for laying hens $(\mathrm{P}>0.05)$. 
Table 4. Average Egg Mass of Laying Hens At Wakhid Farm Magetan Regency (gram/grain/day)

\begin{tabular}{ccccc}
\hline \multirow{2}{*}{ Repeition } & \multicolumn{4}{c}{ Handling } \\
\cline { 2 - 5 } & $\mathrm{P}_{0}$ & $\mathrm{P}_{1}$ & $\mathrm{P}_{2}$ & $\mathrm{P}_{3}$ \\
\hline $\mathrm{U}_{1}$ & 59.80 & 53.60 & 49.57 & 62.00 \\
$\mathrm{U}_{2}$ & 39.57 & 50.67 & 53.07 & 57.39 \\
$\mathrm{U}_{3}$ & 45.67 & 43.89 & 47.85 & 52.21 \\
$\mathrm{U}_{4}$ & 44.32 & 40.98 & 52.30 & 54.60 \\
\hline Average $^{\text {ns }}$ & 47.34 & 43.94 & 50.69 & 56.55 \\
\hline Description $^{\text {ns }}$ : Non Significant & & &
\end{tabular}

The lowest egg mass data was obtained in the $\mathrm{P}_{0}$ treatment of 47.34 and the highest in the $\mathrm{P}_{3}$ treatment of 56.55. The results of this study are in accordance with Amrullah (2003) daily and egg weight. If egg mass increases then egg production increases, otherwise egg mass decreases egg production decreases. The time of taking eggs in treatment $\mathrm{P}_{0}, \mathrm{P}_{1}, \mathrm{P}_{2}$ and $\mathrm{P}_{3}$ on average was carried out at $14.00-15.00$. Based on the results of the study, it can be seen that from the four treatments the lowest egg mass data was 47.34, where the $\mathrm{P}_{0}$ treatment averaged egg retrieval time at $14.00-15.00$.

\section{Conclusion}

Based on the results of the research above, it can be concluded that the performance of laying hen eggs with the addition of sprouts at Wakhid Farm, Magetan Regency is included in the good category; this can be seen from the results of observations of feed consumption, which is between 118.7 - 118.5 grams / hen / day, Hen Day Production is between $79.46-90.17 \%$, egg mass is between $43.94-56.55 \mathrm{~g} / \mathrm{egg} / \mathrm{day}$ and egg weight is between $57.08-60.47$ grams.

\section{References}

Didik. N, M. Halim dan Djunaidi. 2018. Pengaruh Penambahan Ekstrak Daun Jati (Tectona Grandis Linn. F) Dalam Pakan Terhadap Performa Ayam Petelur. Jurnal Nutrisi Ternak Tropis. Vol 1(1) : 1-39.

Kurtini. T, Septinova. D dan Nova. K. 2014. Produksi Ternak Unggas. Anugrah Utama Raharja : Bandar Lampung.

Larasati. G.A.A, Mahfudz. L. D dan Sarengat. W. 2017. Pengaruh Penggunaan Ampas Kecap Dalam Ransum Terhadap Performa Itik Mojosari. Jurnal Peternakan Indonesia. Vol 19(2) : 76-80.

Puspitasary. D, Pujaningsih. R. I dan Mangisah. I. 2018. Pengaruh Pemberian Pakan Mengandung Limbah Tauge Kacang Hijau Fermentasi Terhadap Konsumsi Ransum, Pertambahan Bobot Badan, dan Konversi Ransum Itik Lokal. Agromedia. Vol 36(1) : 61-66. 
Sari. M. E. suprijatna dan W. Sarengat. 2017. Pengaruh Sinbiotik Untuk Aditif Pakan Ayam Petelur Terhadap Kandungan Kimiawi Telur. Jurnal Peternakan Indonesia. Vol 19(1) : 16-22.

Zainal. A. 2003. Meningkatkan Produktivitas Ayam Ras Petelur. PT. Agromedia, Jakarta. 